\title{
Enhancing the assignment
} Using the Framework for student learning and assessment in a Business Law class

I $\mathrm{n}$ this column, I discuss my usage of three different frames of the ACRL "Framework for Information Literacy for Higher Education." I I worked with knowledge practices and dispositions from three frames in a 75-minute library instruction class for the Business and Law course "Legal Environment of Business." I used those frames to enhance simple instruction for the class, and created an assessment to complement the instruction.

\section{Library instruction in Business and Law classes}

A typical Business or Law library instruction class may not look like other library instruction classes. They require specialized information found in multiple databases, which needs to be searched a certain way. For example, a student who is asked to find company financial data as part of an overall marketing plan cannot type into EBSCO's Business Source Premier's search box "company information" AND (company name). The results would be ineffectual: there would be details and news articles about the company, but not the company's financial data or balance sheets.

Many business classes have similar assignments - very structured with lots of information needed from multiple parts of multiple sources, as opposed to "Find six or eight sources from books and articles" assignments. They can be intimidating to work with and difficult to determine how to add in overarching information literacy concepts and skills. This concept is not new to librarians. Kathy Shields and Christine
Cugliari, ${ }^{2}$ for this very same column, discussed a nonprofit management class assignment in regards to the Framework.

\section{Background}

The aforementioned course is offered each semester at William Paterson University. Each semester, one of the professors teaching it requests instruction from the library. I have been conducting library instruction for this course and this professor each semester since fall 2014. My first attempt with working with the Framework and this course was to design a collaborative learning exercise, which I piloted in spring 2016 and continued during the next two semesters.

During the spring 2017 semester, I was given a different challenge. After a brief presentation to the class earlier in the semester, I was approached towards the end of the semester to come to the class again, this time to deliver more detailed library instruction as it pertained to an in-depth assignment. I tried using the Framework in a different way.

\section{Integrating the Framework when the assignment is already built}

For this class, I was given very specific instructions from the instructor to follow a complex assignment she created for the stu-

Cara Berg is reference librarian/co-coordinator user education atWilliam Paterson University, email: bergc1@ wpunj.edu

() 2017 Cara Berg 
dents in using LexisNexis and quality newspaper sources (e.g., The Wall Street Journal) to solve questions.

Once I met with the professor and had her assignment, I wrote learning outcomes using the Framework as a guide. Whereas without a structured assignment, I might have had more freedom, with it the questions "guided" me to selecting the frames I wanted to work with.

I have struggled with the concept of the frames in class-How many are we supposed to use in a one-shot or a two-shot? Do we cover all the knowledge practices/dispositions in a given frame at once?

Alleviating my anxiety was the knowledge that the Framework was designed to be flexible. The flexibility of the Framework ultimately led me to crafting my learning outcomes, while still using the assignment. With that in mind, I set to begin integrating the frames into my learning outcomes.

While I did not cover every Knowledge Practice or Disposition from them, I chose to focus on three frames:

- Authority is Constructed and Contextual;

- Information Creation as a Process; and

- Searching as Strategic Exploration

My learning outcomes were:

- Students will understand and articulate the difference between a case, a law review, and a journal article. (Searching as Strategic Exploration, Information Creation as a Process)

- Students will successfully navigate LexisNexis to retrieve a case and modify it to better assist their search. (Searching as Strategic Exploration)

- Students will locate and work with company shareholder reports and 10-K reports (Searching as Strategic Exploration, Authority is Constructed and Contextual)

- Students will identify and locate quality news sources (Authority is Constructed and Contextual, Searching as Strategic Exploration)

In previous years, I had taught to the assignment, as the professor had directed. This time, I used the Framework to enhance my in-class presentation to the students. Instead of taking them through the assignment and showing them how to find correct answers, I used concepts in the Framework to teach them additional information literacy skills.

One such example of this came when showing the students how to find a case in LexisNexis. Using the "Information Creation as a Process" frame, I showed them how to find the case, but I also explained why the case was presented the way it was, how LexisNexis had access to the case, and how the case may look in other media. With the "Information Literacy Competency Standards for Higher Education" I would have approached it differently, but the Framework helped me to enhance my content and enhance the students' assignment. The nonlinear structure of the Framework proved to be an asset.

\section{Using the Framework to design a qualitative and quantitative assessment}

In past years, the frames used were "Information Has Value," "Information Creation as a Process," and the easy "Searching is Strategic Exploration." The first assessment was designed around those frames. However, the most helpful comments came from a generic "What did you learn" question. While that was helpful, and it was insightful to map that information to the individual frames, I wanted to be able to show a clear path from the instructional content to the assessment as it relates to the frames.

Of the eight assessment questions, three were generic questions that could be used in any sort of library class in relation to a certain database or skill. The questions were about confidence in using the resource, confidence after receiving instruction, and students being able to recall one thing they learned.

Five more specific questions centered on individual skills were used during the class. One was procedural, asking students how to access The Wall Street Journal from the library's homepage. The rest of the questions were linked to concepts taught in the class.

Two weeks after the class, the professor emailed my survey to the students, provid- 


\begin{tabular}{|c|c|c|c|}
\hline Question & $\begin{array}{l}\text { Question } \\
\text { Type }\end{array}$ & Answer & $\begin{array}{c}\text { Corresponding Frame/ } \\
\text { Knowledge Practice/ } \\
\text { Disposition }\end{array}$ \\
\hline $\begin{array}{l}\text { This is a scholarly publica- } \\
\text { tion written by scholars in } \\
\text { the field of law. You can } \\
\text { find these in LexisNexis. }\end{array}$ & Multiple choice & $\begin{array}{l}\text { Law Reviews } \\
\text { (Options for selection } \\
\text { were cases, statutes, or } \\
\text { law reviews) }\end{array}$ & $\begin{array}{l}\text { Information Creation as a Process } \\
\text { - Knowledge Practice: Assess } \\
\text { the fit between an information } \\
\text { product's creation process and a } \\
\text { particular information need } \\
\text { - Disposition: Value the process } \\
\text { of matching an information need } \\
\text { with an appropriate product }\end{array}$ \\
\hline $\begin{array}{l}\text { What does it mean to } \\
\text { Shepardize }^{3} \text { a case? }\end{array}$ & Short answer & $\begin{array}{l}\text { Acceptable answers } \\
\text { indicated checking to } \\
\text { see if the case was still } \\
\text { good law }\end{array}$ & $\begin{array}{l}\text { Information Creation as a Process } \\
\text { • Knowledge Practice: Recog- } \\
\text { nize the implications of informa- } \\
\text { tion formats that contain static or } \\
\text { dynamic information } \\
\text { Searching as Strategic Exploration } \\
\text { • Knowledge Practice: Under- } \\
\text { stand how information systems } \\
\text { (i.e., collections of recorded infor- } \\
\text { mation) are organized in order to } \\
\text { access relevant information }\end{array}$ \\
\hline $\begin{array}{l}\text { This report is submitted } \\
\text { to the US Securities and } \\
\text { Exchange Commis- } \\
\text { sion for publicly traded } \\
\text { companies. }\end{array}$ & Multiple choice & $\begin{array}{l}\text { 10-K } \\
\text { (Options for selection } \\
\text { were 10-K, Annual Share- } \\
\text { holder Report, or Balance } \\
\text { Sheet). }\end{array}$ & $\begin{array}{l}\text { Information Creation as a Process } \\
\text { - Knowledge Practice: Rec- } \\
\text { ognize that information may be } \\
\text { perceived differently based on the } \\
\text { format in which it is packaged } \\
\text { Searching as Strategic Exploration: } \\
\text { - Disposition: Realize that } \\
\text { information sources vary greatly } \\
\text { in content and format and have } \\
\text { varying relevance and value, de- } \\
\text { pending on the needs and nature } \\
\text { of the search }\end{array}$ \\
\hline
\end{tabular}

ing an extra credit incentive to complete the survey. Thirty students completed the survey.

\section{Assessment results/discussion}

I was pleased with the results of the assessment overall. In the question "Name one thing you learned (but please be specific)," many students listed new tips and tricks they learned from the session. Many of the comments reflected the "Searching is Strategic Exploration" frame, with comments including how to modify search results, correctly search with Lexis's modifiers, and access different databases. Twenty-nine out of 30 students correctly answered this question (the person who answered it incorrectly just typed in " $\mathrm{D}$ ").

I used student responses to gauge the correct answer to two of the three open- ended questions using a rubric designed for this assessment. Correct answers on the Shepards question indicated an understanding that the Shepardize option allows the user to see what has happened to the case since the decision and if it's still considered "good law." This relates back to two of the frames-in acknowledging the dynamic information provided by a Shepards citation and in being able to understand and locate the Shepards summary. 


\begin{tabular}{|l|l|l|l|}
\hline \multicolumn{1}{|c|}{ Question } & \multicolumn{1}{c|}{$\begin{array}{c}\text { Question } \\
\text { Type }\end{array}$} & \multicolumn{1}{c|}{ Answer } & \multicolumn{1}{c|}{$\begin{array}{c}\text { Corresponding Frame/ } \\
\text { Knowledge Practice/ } \\
\text { Disposition }\end{array}$} \\
\hline $\begin{array}{l}\text { Click on the library } \\
\text { homepage. If you want } \\
\text { to find an article from The } \\
\text { Wall Street Journal, what } \\
\text { would you click on? }\end{array}$ & Procedural & Journals A-Z & $\begin{array}{l}\text { Searching as Strategic Exploration } \\
\text { - Knowledge Practice: Match } \\
\text { information needs and search } \\
\text { strategies to appropriate search } \\
\text { tools }\end{array}$ \\
\hline $\begin{array}{l}\text { In your assignment, } \\
\text { you were asked to find } \\
\text { articles using sources like } \\
\begin{array}{l}\text { The Washington Post, The } \\
\text { New York Times, or The } \\
\text { Wall Street Journal. What } \\
\text { makes those credible } \\
\text { sources? }\end{array}\end{array}$ & Short answer & $\begin{array}{l}\text { Acceptable answers } \\
\text { included listing that the } \\
\text { sources were trusted, } \\
\text { used credible and } \\
\text { verified sources, and/or } \\
\text { information vetted by } \\
\text { editor }\end{array}$ & $\begin{array}{l}\text { Authority is Constructed and } \\
\text { Contextual } \\
\text { - Knowledge Practice: Recog- } \\
\text { nize that authoritative content } \\
\text { may be packaged formally or in- } \\
\text { formally and may include sources } \\
\text { of all media types } \\
\text { - Disposition: Develop and } \\
\text { maintain an open mind when en- } \\
\text { countering varied and sometimes } \\
\text { conflicting perspective }\end{array}$ \\
\hline
\end{tabular}

\begin{tabular}{|l|c|}
\hline & $\begin{array}{c}\text { Number of Stu- } \\
\text { dents Answering } \\
\text { Correctly }\end{array}$ \\
\hline $\begin{array}{l}\text { This is a scholarly publication written by scholars in the field of law. You can find these } \\
\text { in LexisNexis. }\end{array}$ & 28 \\
\hline What does it mean to Shepardize a case? & 24 \\
\hline $\begin{array}{l}\text { This report is submitted to the US Securities and Exchange Commission for publicly } \\
\text { traded companies. }\end{array}$ & 21 \\
\hline $\begin{array}{l}\text { Click on the library homepage. If you want to find an article from The Wall Street Jour- } \\
\text { nal, what would you click on? }\end{array}$ & 23 \\
\hline $\begin{array}{l}\text { In your assignment, you were asked to find articles using sources like The Washing- } \\
\text { ton Post, The New York Times, or The Wall Street Journal. What makes those credible } \\
\text { sources? }\end{array}$ & \\
\hline
\end{tabular}

Correct answers on the source question looked to see students go beyond the simple "it's in the library" and indicate that the sources listed were well-trusted, reputable sources that had journalistic standards and relied on their own credible sources, relating it back to the Authority is Constructed and Contextual frame.

In the questions directly relating to the Framework, the results were positive, showing students' understanding of the concepts:

From the assessment results, the students were able to mostly correctly answer questions that directly related to Framework-related topics shown in class. In addition to completing the assignment using newfound knowledge, they learned about searching the library's databases, the credibility of sources, and how information appears in different sources and locations.

\section{Future use of the Framework in Business}

Using the Framework to better teach an existing assignment proved to be successful. Instead of procedurally showing the students how to answer the questions on their assignment, I used the three frames to paint their assignment in a larger context. I devel-

(continues on page 520) 
information for people to be able to develop their communities.

The Jamaican Government in partnership with The University of the West Indies (UWI) and the UN hosted a meeting on June 28-30, 2017. Eighteen Caribbean countries met at the "Caribbean Action 2030" meeting, where UWI Vice Chancellor Hilary Beckles stated that, "The realization of the SDGs will be intellectually exciting and operationally challenging, but working together they are more than attainable." ${ }^{3}$ This is seen as a step in the right direction, which will aid SDGs implementation in the region.

The Global Alliance for Partnerships on Media and Information Literacy is one area in which academic libraries in Jamaica can be included by embarking on media and information literacy workshops to educate tertiary-level students and train them with updated ICT skills and other competencies, such as the ability to critically evaluate information and use it wisely on the Internet. At UWI-Mona, this is realized through compulsory two-hour information literacy library sessions with the Foundation English courses each semester.
These sessions allow librarians to assist students in being independent information users which make them far more accountable learners, and in turn, foster positive development. During Global Media and Information Literacy Week 2017, a conference will be held October 24-27, 2017, in Kingston, Jamaica, with special emphasis on youth.

There will be a forum at the UWI-Mona, an active partner in this conference. Academic libraries playing a part in advancing the SDGs is essential as an educated populace is crucial for development.

\section{Notes}

1. Planning Institute of Jamaica (PIOJ). "Executive Summary." Accessed August 23, 2017. http://www.vision2030.gov.jm/Portals/0 /NDP/Executive\%20Summary.pdf.

2. Statistical Institute of Jamaica (STATIN). "A road map for SDG implementation in Jamaica." Accessed August 23, 2017, http://statinja.gov.jm/pdf/JamaicaSDGRoadmap.pdf.

3. UWI Nexus. "The 17 SDGs addressed at Caribbean Action 2030." Accessed August 23, 2017. https://www.uwi.edu/alumnionline/ civicrm/mailing/view?reset=1\&id=84.

("Enhancing the assignment," continues from page 505)

oped my own learning outcomes around an existing assignment, and then designed an assessment directly relating to those learning outcomes.

With the flexibility and generality of the Framework, I was able to use it to work for me and guide me to my learning outcomes, my class, and then my assessment. The Framework works well in Business classes as a way to bring assignments more into the scope of information literacy. A partnership where the librarian helps design the assignment using the Framework would also be effective.

I look forward to my continued use of the Framework in Business classes. The Framework took a routine class and integrated information literacy concepts, while still abiding by the professor's wishes. The flexibility of the Framework allowed me to select the frames, knowledge practices, and dispositions that would be the best for the students.

It is my hope to continue to work with the Business faculty in integrating the Framework into library instruction classes, or perhaps even into assignments.

\section{Notes}

1. ACRL, "Framework for Information Literacy for Higher Education,” January 2016, www.ala.org/acrl/standards/ilframework.

2. Kathy Shields and Christine Cugliari, "Scholarship as Conversation: Introducing Students to Research in Nonprofit Studies," CERL News, 78, no. 3, March 2017

3. In LexisNexis, the Shepards Citation will show users if a case is still good law (i.e., has the case received negative treatment or been overturned?). 